\title{
Effect of the source of carbohydrate supplement on bacterial adhesion and digestion of straw cell wall
}

\author{
A Barrios 1, M Fondevila 2, JM Peiro 2, C Castrillo 2 \\ 1 Facultad de Agronomia, Universidad del Zulia, 526 Maracaibo, Venezuela; 2 Dpto. Produccion Animal \\ y Ciencia de los Alimentos, Universidad de Zaragoza, 50013 Zaragoza, Spain
}

It has been shown that the source of carbohydrate supplement affects the ability of rumen bacteria to digest forage cell wall. It is not clear whether the effect depends on the extent of $\mathrm{pH}$ reduction induced by supplementation (Hiltner and Dehority, 1983, Appl Environ Microbiol, 46, 642-648), or on both $\mathrm{pH}$ and the affinity of cellulolytic bacteria for the supplement, thus delaying digestion (Stewart, 1977, Appl Environ Microbiol, 33, 497-502). This work aimed to determine in vitro which type of carbohydrate would allow a larger adhesion and digestion of barley straw cell wall by mixed rumen bacteria.

Culture media (Scott and Dehority, 1965, J Bacteriol, 89, 1169-1175) were prepared with cell wall from straw as substrate $10.5 \%$ w/v)(Smith and Waldo, 1969, J Dairy Sci, 52, 2051-2053) and tested unsupplemented (CW) or with $0.27 \% \mathrm{w} / \mathrm{v}$ soluble starch (S), pectin $(\mathrm{P})$ or a mixture $(25 \%$ each) of glucose, maltose, fructose and sucrose (M). Media were dispensed $(8 \mathrm{ml})$ anaerobically into Hungate tubes, inoculated $(1 \mathrm{ml})$ with rumen fluid from a sheep fed on straw and alfalfa hay $(50: 50)$ and diluted $1: 10$. After incubation at $39^{\circ} \mathrm{C}(4$ tubes/treatment), $\mathrm{pH}$ was recorded. Bacterial adhesion was determined in the washed fermentation residue from the purine base concentration measured by HPLC after 4,8 , $12,20,24$ and $32 \mathrm{~h}$ incubation. Cell-wall digestion was measured by analysis of residual monosaccharides (Theander and Westerlund, 1986, J Agric Food Chem, 34, 330-336) after $12,24,36,48,60$ and $72 \mathrm{~h}$ compared to uninoculated medium.

Bacterial adhesion and cell wall disappearance were low $(\mathrm{P}<0.001)$ and $\mathrm{pH}$ higher $(P<0.001)$ in $C W$ than in the other media. Differences in $\mathrm{pH}$ among supplemented media were less than 0.1 units at any sampling time. Bacterial adhesion in $P, S$ and $M$ reached a plateau at $20 \mathrm{~h}$, and only small increases (5$7 \%$ ) were observed from 20 to $32 \mathrm{~h}$. However, adhesion ( $\mu \mathrm{mol}$ purine bases/mg dry residue) at 8 and $12 \mathrm{~h}$ was higher $(\mathrm{P}<0.05)$ with $\mathrm{P}$ (11.89 and 9.53 ) than with $S$ (4.72 and 6.40) or $M(4.58$ and 5.68$)$. Residual glucose from cell wall digestion (see table) was lower $(P<0.05)$ in $P$ than in $S$ after 36,60 and $72 \mathrm{~h}$, and lower than in $M$ after 60 and 72 h. Xylose and arabinose in the residue followed similar trends.

Supplementation of cell wall with pectin promoted a faster bacteria adhesion and a higher monosaccharide release than starch or soluble sugars, and the response was not related to differences in $\mathrm{pH}$.

\begin{tabular}{|c|c|c|c|c|c|c|c|c|c|}
\hline & & Glucose & & & Xylose & & & Arabinose & \\
\hline $\begin{array}{l}\text { Residual } \\
\text { sugars* }\end{array}$ & $24 \mathrm{~h}$ & $\overline{36 \mathrm{~h}}$ & $\overline{72 h}$ & $\overline{24 \mathrm{~h}}$ & $36 \mathrm{~h}$ & $\overline{72 h}$ & $\overline{24 h}$ & $\overline{36 \mathrm{~h}}$ & $72 \mathrm{~h}$ \\
\hline $\mathrm{CW}$ & 83.0 & 70.4 & 84.6 & 95.2 & 76.1 & 89.1 & 80.1 & 61.0 & 75.5 \\
\hline$S$ & 53.4 & 32.4 & 23.1 & 87.1 & 45.4 & 32.8 & 50.9 & 32.0 & 26.0 \\
\hline$P$ & 50.5 & 27.6 & 16.2 & 72.1 & 37.6 & 23.5 & 51.1 & 31.5 & 23.4 \\
\hline M & 52.3 & 30.8 & 27.8 & 70.0 & 42.8 & 42.5 & 50.7 & 31.7 & 36.3 \\
\hline s.e.d. & 3.09 & 1.41 & 2.18 & 9.64 & 2.24 & 4.03 & 4.81 & 1.72 & 4.14 \\
\hline
\end{tabular}

$\because$ : Expressed as percentage of residual sugars in uninoculated medium. 